\title{
Effects of hunting management on Mediterranean farmland birds
}

\author{
JESÚS CARO, MIGUEL DELIBES-MATEOS, ALBA ESTRADA, RUI BORRALHO, \\ LUÍS GORDINHO, LUÍS REINO, PEDRO BEJA and BEATRIZ ARROYO
}

\begin{abstract}
Summary
Hunting and its associated management have significant costs and benefits for biodiversity conservation, which makes this socio-economic activity highly controversial at both international and regional levels. We investigated relationships between management for small game species (mainly Red-legged Partridges Alectoris rufa and rabbits Oryctolagus cuniculus) and both abundance and richness of farmland and scrubland songbirds, raptors and ground-nesting birds, and on the abundance of three species of conservation concern (Little Bustard Tetrax tetrax, Eurasian Thick-knee Burhinus oedicnemus and Montagu's Harrier Circus pygargus) in southern Portugal farmland. We compared 12 game estates and 12 matching areas with similar sizes and land uses but no game management. Richness and abundance were estimated from fixed point counts, and were related to game regime (managed or unmanaged), habitat characteristics and census period. Our results showed that game management was associated, albeit weakly, with higher abundance of raptors and ground-nesting birds, but no relationship (either positive or negative) was found for other guilds and species. Habitat was generally the most important factor explaining bird species richness and abundance. Our results suggest possibilities for promoting management systems that could maximize both hunting sustainability and conservation value of managed areas, particularly when management helps to improve or maintain beneficial habitats or practices for farmland birds.
\end{abstract}

\section{Introduction}

The increasing pressure from human activities implies that current rates of biodiversity loss are unparalleled in historical times (Mace et al. 2005). There is a widespread agreement among a variety of stakeholders that halting biodiversity loss will only be possible through the implementation of land-use strategies that integrate the needs of both human activities and biodiversity conservation (Woodroffe et al. 2005). Hunting is one of those activities that interact with biodiversity, and all over the world it is undertaken by millions of people over large areas across a broad range of ecosystems (Mustin et al. 2011).

A number of studies have exemplified negative impacts of hunting on biodiversity through overexploitation (Halliday 1980, Keane et al. 2005), and disturbance of wildlife (Evans and Day 2002, Casas et al. 2009). Also, undesirable effects of some game management practices on both game and non-game species have been documented; e.g. the release of farm-reared animals for shooting may compromise the genetic integrity of some game species (Blanco-Aguiar et al. 2008, Chazara et al. 2010), and predator control carried out by hunters may threaten some predators of conservation concern (Whitfield et al. 2003). In contrast, other studies have pointed out that hunting may contribute to biodiversity conservation, highlighting the potential for hunters to be active collaborators with conservation organizations (Paulson 2012). For example, game management may contribute to safeguard valuable habitats for biodiversity on private land 
(Oldfield et al. 2003), and may also benefit other non-target species through the provision of food or the removal of generalist predators (Stoate and Szczur 2001, Beja et al. 2009). Overall, the relationships between hunting and biodiversity are still a matter of controversy among researchers, conservationists and the general public, at both international and regional levels (Mustin et al. 2011).

Most studies addressing the effects of hunting on biodiversity have been carried out in northern Europe, whereas species and populations from more diverse southern European ecosystems have received less attention (but see Suárez et al. 1993, Stoate et al. 2000, Beja et al. 2009). There is thus a need to examine the interactions between hunting and biodiversity in a wider range of ecological circumstances and geographic regions, thereby helping to develop generalisations that may be useful in setting guidelines for enhancing the conservation value of game management, while decreasing some of its negative impacts. The Iberian Peninsula is a region where examining these issues is particularly relevant, both because of its importance from the conservation standpoint (Myers et al. 2000), and also because hunting there is a significant and widespread socioeconomic activity (Martínez et al. 2002).

In principle, the potential impact of hunting on biodiversity will depend not only on the occurrence of the activity as such, but also on the management applied, including the regulation of animals hunted (i.e. whether extraction is adjusted in relation to abundance), and the management tools applied with the objective of improving populations of game. In fact, game management to boost game populations is becoming progressively more intensive in the Iberian Peninsula, which may have negative consequences for biodiversity (Virgós and Travaini 2005, Villanúa et al. 2008, Macaulay et al. 2013). For example, the decline of the Red-legged Partridge Alectoris rufa and the European rabbit Oryctolagus cuniculus, mainly as a consequence of changes in agricultural practices, overhunting or epidemic diseases (Villafuerte et al. 1995, Blanco-Aguiar et al. 2004), has led to increases in potential detrimental practices, such as the large scale release of farm-reared animals (Blanco-Aguiar et al. 2008), and the implementation of intensive predator control campaigns (Villafuerte et al. 1998). In contrast, some studies suggested that actions aimed at benefitting small-game species in Iberian contexts may also have positive consequences on other species sharing the same habitats, such as predator control benefitting ground-nesting passerines (Suárez et al. 1993) or the provision of water points benefitting some farmland bird species (Gaudioso Lacasa et al. 2010). Additionally, in this region, income from hunting can provide an economic incentive to maintain areas of relatively undisturbed wildlife habitat, including high conservation value 'montados' and 'dehesas' (areas of sparse oak Quercus spp. woodland which may be cultivated or grazed underneath; see Díaz et al. 2009, Macaulay et al. 2013). Overall, we can presume that hunting may have conservation value if it improves populations of game and other wild species (especially species of conservation concern) or, at least, if it is not harmful to species of conservation concern and contributes to maintain the viability of high-value land-use systems.

Within this context, the aim of this study was to investigate the effects of game management on non-game species in the Iberian Peninsula. The study focused on farmland bird assemblages, because small game hunting mainly occurs on farmland, and farmland birds have suffered major population declines at the European level in recent decades, mainly due to agricultural intensification (Donald et al. 2001, BirdLife International 2004). Specifically, the study was based on a treatmentcontrol natural experiment, comparing areas with and without management for small game species in southern Portugal, and analysing the relative effects of game management and habitat conditions on: (i) species richness and abundance of species grouped according to ecological characteristics; and (ii) abundance of individual species of conservation concern. Results were then used to discuss the conservation implications of game management in Mediterranean farmland.

\section{Methods}

\section{Study area}

The study was conducted in the region of Alentejo, southern Portugal (Figure 1). Climate is Mediterranean, with hot summers, fairly cold winters and $>75 \%$ of annual rainfall $(500-700 \mathrm{~mm})$ 


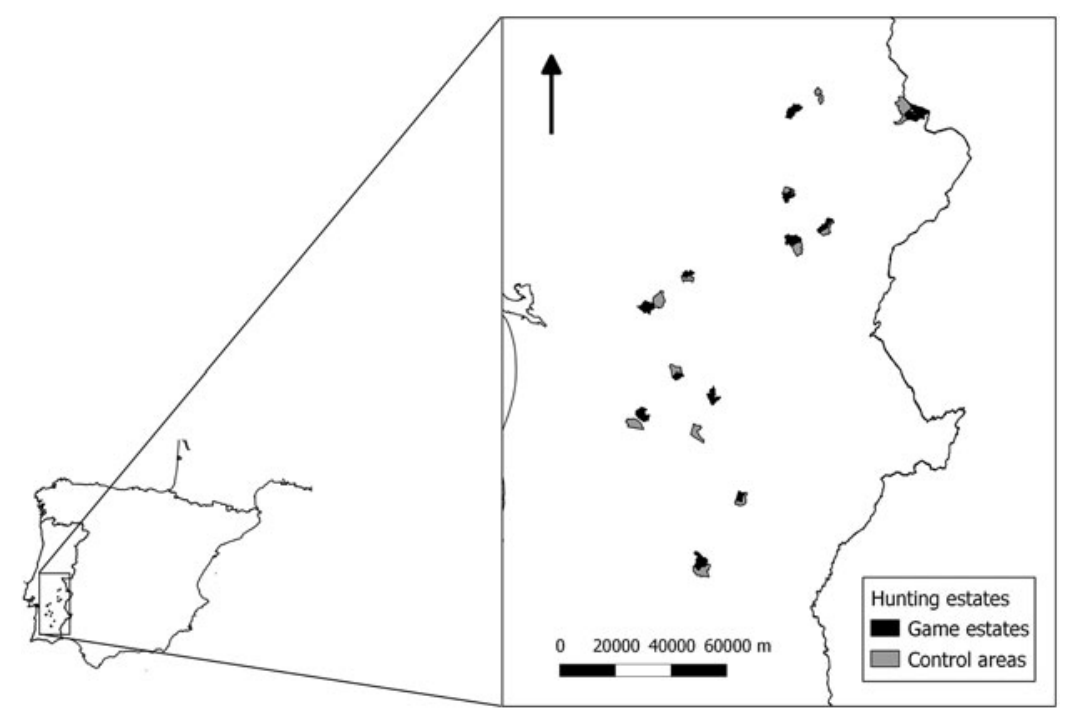

Figure 1. Location of the study area in southern Portugal.

concentrated in October-March. The landscape is dominated by savanna-like woodlands ('montados') of cork oak Quercus suber or holm oak $Q$. ilex, with understorey frequently grazed by cattle, sheep and pigs. Other important land uses include annual crops (mostly winter cereals, e.g. barley Hordeum vulgare, wheat Triticum spp.) and permanent crops (e.g. olive groves Olea europaea, vineyards Vitis vinifera), as well as pine Pinus spp. and eucalyptus Eucalyptus spp. plantations. There are marked trends for agricultural intensification in the most productive areas, as well as scrub encroachment and afforestation in marginal agricultural lands (Pinto-Correia and Mascarenhas 1999, Van Doorn and Bakker 2007).

Hunting is important in Alentejo, involving both residents and a large number of hunters from urban centres throughout the country. In recent years, the economic importance of hunting has increased along with modifications in hunting regulations and the decline of traditional rural economies (Van Doorn and Bakker 2007). Hunting regimes changed from open hunting in the mid-1970s, in which there was neither game management nor restrictions of access to hunting areas, to the present situation of primarily private hunting estates, with large areas managed by hunter associations or landowners (Coelho 2011).

\section{Sampling design}

The study was akin to a treatment-control natural experiment, involving comparisons between 12 estates managed to promote game species (private hunting regime, hereafter 'Game estates'), and 12 matching control areas, open to hunters but with no game management (open hunting regime, hereafter 'Control areas') (Figure 1). Hunting estates were randomly selected from a database of all hunting estates in Alentejo, and Game estates and Control areas were required to be as similar as possible, both in terms of size, habitat and land use (see Beja et al. 2009 for details). All Game estates and Control areas selected were required to have more than three years of continuous similar conditions in terms of game management.

Mean surface area and standard deviation of the 24 areas was $12 \pm 6 \mathrm{~km}^{2}$ (range 5.5-25.7). Management practices were assessed from enquiries to landowners and game managers, but they could not be quantified in detail for each study area because in most cases the information provided was incomplete. However, enquiries revealed that all game estates provisioned water and grain 
(watering and feeding sites), 91.7\% admitted carrying out predator control (the single exception did not provide information), at least $41.7 \%$ cultivated game crops to provide cover and food for game species, and at least 91.7\% released small game, mainly Red-legged Partridge (eight estates) and European rabbit (five estates). More details can be found in Beja et al. (2009). Species legally controlled were red foxes Vulpes vulpes, Egyptian mongooses Herpestes ichneumon, feral cats Felis catus, dogs Canis familiaris, Carrion Crows Corvus corone, Eurasian Jays Garrulus glandarius and Common Magpies Pica pica. The illegal culling of protected carnivores and birds of prey occurred to an unknown extent (Beja et al. 2009).

\section{Avian surveys}

Field surveys were carried out in 2000 and 2001. Thirty point counts were randomly selected in each of the 24 study sites. Point selection was restricted to land uses covering more than $5 \%$ of the total area. To minimise the probability of overlapping counts, a minimum distance of $700 \mathrm{~m}$ between successively census points was used. Each set of thirty points consisted of three different sub-sets of points, each one visited in one of the three sampling periods during the breeding season: early season (late March to mid-May), mid-season (late April to early June) and late season (midJune to mid-July). On average, each subset consisted of 1 o points, but there was some variation among areas $(S D \pm 2.7)$ due to logistic constraints. In each sampling period, surveyed points were widely scattered along tracks distributed throughout the whole of the estate. This sampling protocol aimed to obtain a more realistic census of the breeding community, given the large temporal variation in breeding phenology and activity among bird species in southern Portugal, including sedentary and migratory species (both pre- and trans-Saharan migrants). A total of 91.1\% of point counts were conducted by a single experienced observer (LG), and the remaining by an equally experienced observer (LR). We identified all individuals and flocks seen or heard, during I5 minutes in each sampling point. Bird censuses were made during the first three hours after dawn and the last three hours before dusk, corresponding to the period of highest bird activity. Each Game estate and its corresponding Control area were always sampled by the same observer, on consecutive days, at around the same time.

\section{Bird guilds}

Bird species were clustered in four ecological groups (guilds; see Verner 1984): farmland songbirds, scrubland songbirds, raptors, and medium-sized ground-nesting birds, mainly steppe-birds (a list of all species can be found in Table $S_{1}$ in the online Supplementary Materials). The focus on songbirds (i.e. all Passeriformes except the family Corvidae) is justified, because this heterogeneous group of species (Tellería et al. 1999) is a widely used indicator of both habitat and wildlife conservation value (Stoate and Szczur 2001, Litteral and Wu 2012, Morales et al. 2012). Farmland songbirds were considered because previous studies have shown that they may be favoured by cultivation of game crops and by seeds provided in feeding stations for game (Mustin et al. 2011), as well as by reduced predation pressure due to predator control (Yanes and Suárez 1996), and so they could be expected to react positively to game management. Scrubland songbirds were considered because they might also be favoured by reduced predation pressure, though they are unlikely to be affected by the provisioning of seeds and game crops. We excluded Spotless Starling Sturnus unicolor from analyses, as the much higher abundance of Spotless Starling in Control areas ( 1,860 contacts) than in Game estates (870 contacts) was likely to be unrelated to game management, probably resulting to a large extent from more unoccupied rural constructions in non-managed areas (LG and LR pers. obs.), which may enhance breeding sites for the species (Tellería et al. 1999).

The guild of raptors included diurnal birds of prey and owls feeding at least occasionally on small game species (rabbits or partridges). This guild was considered because it includes species of conservation concern, which may either benefit from management due to an increase of small 
prey abundance (Delibes-Mateos et al. 2007), or be negatively affected if illegal control is directed against predators seen as competitors by hunters (Beja et al. 2009).

The ground-nesting guild included medium-sized bird species and one wader (Pratincole Glareola pratincola), which frequently uses farmland areas. We excluded ground-nesting songbirds and raptor species to avoid representation of species in more than one guild. Additionally, we excluded game species as the Red-legged Partridge, the Common Quail Coturnix coturnix and wildfowl, as these may be affected by shooting pressure, rather than by game management. This guild was considered because it included species of conservation concern, which might be affected by management carried out to increase suitable habitats for breeding and feeding of game birds, as well as by predator control reducing the naturally high predation pressure on ground nests (Yanes and Suárez 1996, Beja et al. 2014).

Finally, we were also specifically interested in evaluating the impact of hunting on individual species of conservation concern in Portugal (Cabral et al. 2008). Among those, we focused our analyses on the species most frequently recorded in our study areas (> 70 observations), including Little Bustard Tetrax tetrax, Eurasian Thick-knee Burhinus oedicnemus and Montagu's Harrier Circus pygargus.

\section{Explanatory variables}

We were interested in evaluating the effect of small game management on richness and abundance of bird guilds (thus testing for differences between Control areas and Game estates) after controlling for habitat variables. The habitat composition of each Game estate and Control area was characterised in terms of six dominant land cover categories (Table 1 ). At each sampling point, the proportion of each land cover category was visually estimated within a $200 \mathrm{~m}$ radius centred on the observer, immediately after the bird count. An overall estimate for each estate was then obtained by averaging the estimates from the 30 points sampled within the estate. Habitats were considered at the level of the entire estate rather than at the scale of each individual point, because we were interested on the overall landscape composition resulting from the joint effects of farmland and game management practices.

Table 1 . Variables measured in the 24 areas and used in the Principal Component Analysis and modelling procedure.

\begin{tabular}{|c|c|}
\hline Variable & Description \\
\hline Census period & $\begin{array}{l}\text { Categorical variable with three different levels: early season } \\
\text { (late March to mid-May), mid-season (late April to early June) } \\
\text { and late season (mid-June to mid-July) }\end{array}$ \\
\hline \multicolumn{2}{|l|}{ Habitat } \\
\hline Open farmland & $\begin{array}{l}\text { Percentage cover of arable land (pastures, cereal fields, fallows } \\
\text { and/or ploughed fields) }\end{array}$ \\
\hline Permanent crops & Percentage cover of olive groves, vineyards and fruit orchards \\
\hline 'Montados' & $\begin{array}{l}\text { Percentage cover of open woodlands dominated by Quercus ilex and/or } \\
\text { Q. suber with pastures, arable crops, or shrubs in the understorey }\end{array}$ \\
\hline Mediterranean scrubland & $\begin{array}{l}\text { Percentage cover of medium-height Mediterranean shrubs, dominated } \\
\text { by species of Cistus, Genista, and Ulex among many others, with } \\
\text { a strong component of Q. ilex and/or Q. suber, the latter sometimes } \\
\text { achieving full tree height }\end{array}$ \\
\hline $\begin{array}{l}\text { Streams, reservoirs and } \\
\text { riparian vegetation }\end{array}$ & $\begin{array}{l}\text { Percentage cover of streams, riparian vegetation, farm ponds, } \\
\text { and small reservoirs }\end{array}$ \\
\hline Forest stands & $\begin{array}{l}\text { Percentage cover of pine Pinus spp. or eucalyptus } \\
\text { Eucalyptus spp. plantations }\end{array}$ \\
\hline \multicolumn{2}{|l|}{ Game category } \\
\hline Game management & $\begin{array}{l}\text { Categorical variable with two different levels: Game estates and } \\
\text { Control areas }\end{array}$ \\
\hline
\end{tabular}


Additionally, as raptors that feed on small game species (rabbits and partridges) may respond positively to small game abundance (Delibes-Mateos et al. 2007), we also considered abundance of both small game species as further explanatory variables for this guild. Partridge abundance was estimated in the surveys described above, and it is presented as total partridges observed in each sampling period in each surveyed area. Rabbits were surveyed once in each area (May-June) from diurnal transects walked along dirt tracks, and observations of individual animals and signs of their presence (faeces) were counted (Beja et al. 2009). Latrines defined as discrete clusters of 20 or more droppings in a $10 \mathrm{~cm}$ radius were used as counting units instead of individual pellets (Calvete et al. 2006).

\section{Statistical analyses}

We modelled richness and abundance of each guild considered, and abundance of individual species of conservation concern. Richness was expressed as the total number of different species observed in each surveyed area and abundance was measured as the total number of individuals observed in each sampling period within each surveyed area (see above). For richness of each bird guild, we used only one value per surveyed area (maximum number of species observed in 30 points), as species richness observed in each estate only reached asymptotic values after c.19-22 points (results not shown here). Prior to this analysis, we $\log _{10}$ $(x+1)$ transformed variables with skewed distributions in order to approach normality and reduce the influence of a few large values (Zar 1999). We initially used the paired t-test to identify differences in abundance and species richness between Game estates and Control areas.

We reduced the six habitat categories into two orthogonal factors using a Principal Component Analysis (PCA; e.g. Atauri and Lucio 2001). Subsequently, we modelled the richness of each guild using Generalised Linear Mixed Models (GLMMs), fitting response variables to a Poisson distribution and using a log link function, and included 'grouping area' (i.e. encompassing each pair of matching Game estate and Control area) as a random effect. As explanatory variables, we used the type of estate (managed or not managed), the two PCA habitat axes, and small game abundance in the case of raptors. We also used GLMMs to model the abundance of each guild and the abundance of the three species of conservation concern, fitting response variables to a Poisson distribution with log link. Response variables were number of individuals observed, and we used as an offset the $\log _{10}$ number of points surveyed. We used as a random term 'surveyed area' (i.e. each Game estate or Control area) nested within 'grouping area', thereby accounting for the repeated observations in each monitored area, and for the lack of independence between each pair of areas due to spatial proximity (see above). Explanatory variables were as above and additionally we included census period as a fixed categorical variable. Models were calculated with the function $\operatorname{glm} m A D M B$ (Fournier et al. 2012), implemented using R statistical software, Version 2.15.1 (R Development Core Team 2011).

We used a model-averaging, information-theoretic approach to assess the magnitude and direction of the effects of predictor variables (Burnham and Anderson 2002). We performed all possible combinations of the independent variables with the R-function dredge (library MuMIn; Bartoń 2012). Models were ranked according to Akaike's Information Criterion $\left(\mathrm{AIC}_{\mathrm{c}}\right.$ for small sample sizes). Akaike weights were also obtained for each model using the R-package AICcmodavg (Mazerolle 2012). Then we calculated an averaged model with all the models that presented a difference of $\mathrm{AIC}_{\mathrm{c}}<2$. Akaike weights indicate the probability that the model is the best among the set of plausible candidate models (Burnham and Anderson 2002), so we calculated the importance of each variable in the averaged model by summing the Akaike weights over all models in which the variable was present (Naidoo et al. 2011). We only interpreted the effects of variables for which the standard errors were smaller than the average coefficient, because otherwise estimates were considered too imprecise. 


\section{Results}

Overall, we observed 22,188 individual birds from 127 species during the censuses. About half of the individuals (48.6\%) were recorded in Game estates and another $51.4 \%$ in Control areas. In terms of guild membership, $13.4 \%$ of the species were classified as farmland songbirds, $25.2 \%$ were scrubland songbirds, $9.4 \%$ were raptors, and $3.9 \%$ were ground-nesting birds. Species that did not belong to any of these groups (48.1\%) were not considered further. Preliminary analyses based on paired t-tests showed no differences in richness and abundance between Game estates and Control areas (paired t-tests, P > 0.05 in all cases, Table 2).

The PCA with habitat variables produced two orthogonal axes which together accounted for more than $95 \%$ of the variance (Table 3 ). The first axis can be interpreted as a gradient from sites dominated by open arable land to those including oak woodlands (whether closed or open). The second axis reflects a gradient of land abandonment, contrasting the 'montados' (open and managed oak woodland) versus encroached Mediterranean scrubland.

Model selection revealed a single candidate model for farmland songbird abundance, groundnesting bird richness and Montagu's Harrier abundance, while there were a rather large number of plausible models for the other guilds and species (Table S2). The model-averaged approach supported the effect of explanatory variables on bird species richness and abundance (Table 4), which we describe subsequently for each guild considered.

\section{Farmland and scrubland songbirds}

Habitat was the most influential variable explaining richness and abundance of both guilds. Species richness and abundance of farmland songbirds increased with rising proportion of open habitat, while richness and abundance of scrubland songbirds declined over the same gradient (Table 4). Census period also affected abundance of farmland songbirds, which was highest in late season and game management was not related to the richness and abundance of both guilds (Table 4).

Table 2. Mean and standard error of richness (total different species observed in each estate) and abundance (number of individuals observed per point) of species guilds in Game estates and Control areas of southern Portugal. Results of paired $t$-tests between groups are also presented. Although most tests were performed on long-transformed data, summary statistics are presented in the original scale.

\begin{tabular}{|c|c|c|c|c|}
\hline & $\begin{array}{l}\text { Control areas } \\
\text { Mean } \pm \text { SD }\end{array}$ & $\begin{array}{l}\text { Game estates } \\
\text { Mean } \pm \text { SD }\end{array}$ & $\mathrm{t}_{11}$ & $P$ \\
\hline \multicolumn{5}{|l|}{ Guild species richness } \\
\hline Farmland songbirds & $10.583 \pm 2.503$ & $11.667 \pm 1.874$ & -2.169 & 0.053 \\
\hline Scrubland songbirds & $12.667 \pm 3.312$ & $13.500 \pm 4.661$ & -0.882 & 0.396 \\
\hline Raptors & $3.500 \pm 0.904$ & $4.000 \pm 1.348$ & -1.483 & 0.166 \\
\hline Ground-nesting birds & $1.417 \pm 1.164$ & $1.333 \pm 1.155$ & 0.432 & 0.674 \\
\hline \multicolumn{5}{|l|}{ Bird abundance } \\
\hline Farmland songbirds & $9.423 \pm 9.726$ & $8.401 \pm 4.014$ & -0.087 & 0.931 \\
\hline Scrubland songbirds & $8.859 \pm 4.770$ & $9.202 \pm 4.538$ & -0.771 & 0.446 \\
\hline Raptors & $0.441 \pm 0.514$ & $0.478 \pm 0.428$ & -1.202 & 0.238 \\
\hline Ground-nesting birds & $0.416 \pm 0.837$ & $0.388 \pm 0.693$ & 0.091 & 0.928 \\
\hline \multicolumn{5}{|l|}{ Bird species abundance } \\
\hline Eurasian Thick-knee & $0.105 \pm 0.191$ & $0.110 \pm 0.197$ & -0.068 & 0.946 \\
\hline Little Bustard & $0.230 \pm 0.573$ & $0.237 \pm 0.522$ & -0.058 & 0.954 \\
\hline Montagu's Harrier & $0.156 \pm 0.325$ & $0.123 \pm 0.260$ & 1.015 & 0.317 \\
\hline \multicolumn{5}{|c|}{ Game species abundance } \\
\hline Red-legged Partridge & $0.155 \pm 0.196$ & $0.468 \pm 0.633$ & -3.276 & 0.002 \\
\hline Rabbit & $0.458 \pm 1.079$ & $5.942 \pm 8.836$ & -2.677 & 0.021 \\
\hline
\end{tabular}


Table 3. Summary results of the Principal Component Analysis of habitat variables.

\begin{tabular}{lcc}
\hline Habitat variable & $\mathrm{PC}_{1}$ & $\mathrm{PC}_{2}$ \\
\hline Open farmland & -0.830 & 0.225 \\
Permanent crops & 0.037 & -0.093 \\
'Montados' & 0.510 & 0.673 \\
Mediterranean scrubland & 0.213 & -0.692 \\
Streams, reservoirs and riparian vegetation & 0.007 & -0.022 \\
Forest stands & 0.061 & -0.089 \\
Eigenvalue & 958.1 & 534.1 \\
Explained variance (\%) & 60.7 & 95.6 \\
\hline
\end{tabular}

\section{Raptors}

Habitat was also the most influential variable explaining richness and abundance of raptors. Game management was also included in the best $\mathrm{AIC}_{\mathrm{c}}$ models for raptor abundance (Table $\mathrm{S}_{2}$ ), which was highest in Game estates (Table 4). The strongest habitat effects were found for $\mathrm{PC}_{1}$, suggesting that both species richness and abundance of raptors were increased with the amount of open land. Finally, abundance was highest earlier in the season (Table 4).

\section{Ground-nesting birds}

Game management was included in the set of best $\mathrm{AIC}_{\mathrm{c}}$ models for ground-nesting bird abundance (for richness, the standard error was higher than the average coefficient), with a tendency for higher abundance in Game estates (Table 4 and Table S2). Again, habitat variables were the most important in explaining ground-nesting bird abundance and richness, which declined with a decrease of open arable land and with an increase in encroachment through land abandonment (Table 4). Abundance was highest earlier in the season (Table 4).

\section{Species of conservation concern}

Game management did not have a significant effect on the abundance of any of the species of conservation concern considered, after taking into account habitat and census period (Table 4 and Table S2). Even if it appeared in the set of best models for the Little Bustard, the standard deviation was higher than the parameter estimate (Table 4 ). Open land was positively related to the abundance of all three species, and there was a strong effect of census period on Little Bustard and Montagu's Harrier, with the highest counts recorded earlier in the season.

\section{Discussion}

Hunting is a traditional activity that may be compatible with the conservation of biodiversity, but that may also threaten biodiversity if sustainable practices are not established (Leopold 1986). We argue that hunting would be detrimental to conservation if it leads to decreases of populations of wild species of conservation concern. Alternatively, it would be beneficial to conservation if it either improves populations of species of conservation concern, or if it is not harmful to those species and contributes to maintain high-value land-use systems. Studies in northern Europe and North America have found either positive or negative effects of hunting or hunting management practices on conservation (Thiollay 2005, Valkama et al. 2005, Mustin et al. 2011).

Until now, there was little information on the effects of hunting and its associated management on non-game birds in Mediterranean ecosystems (Díaz et al. 2009), where farming is still relatively non-intensive and where biodiversity is high (Pain and Pienkowski 1997, Sokos et al. 2013). Broadly, our study did not find any evidence that in game estates there is lower richness or abundance 
of bird guilds, or reduced abundance of species of conservation concern. In contrast, we found some positive associations, albeit relatively weak, between management for small game and the abundance of some guilds that comprise several species of conservation concern. Results thus suggest that some of the management activities carried out within game estates may be beneficial at least for some species, although the magnitude of the effects was small.

We found a positive effect of game management for ground-nesting bird abundance (Table 4) and these could be related to predator control. Predation is an important cause of nest failure and chick survival for Red-legged Partridges, as well as for many other ground-nesting birds (Casas and Viñuela 2010, Magaña et al. 2010 and references therein, Mateo-Moriones et al. 2012). For this reason, on most game estates (including our study area, Methods and Beja et al. 2009) mammalian predator control is a common management practice to reduce predation pressure on game species. Although predator control is aimed at reducing predation on game species, it may also benefit other species, including ground-nesting birds, as controlled carnivore species frequently prey on nest and chicks of these avian species (Fletcher et al. 2010, Magaña et al. 2010, Hartway and Mills 2012). In this sense, a recent study suggested that Egyptian mongooses may be one of the main predators of ground nests in Mediterranean farmland (Beja et al. 2014), and this is one of the species most strictly controlled in game estates of southern Portugal (Beja et al. 2009). In contrast to the predation hypothesis, however, our results did not show a significant relationship between game management and abundance of either Eurasian Thick-knee, Little Bustard or Montagu's Harrier (all ground-nesting species). This may be because our sampling protocol was not accurate enough to detect differences for individual species, as differences between managed and unmanaged areas were overall small. Alternatively, this may suggest that the relationship between game management and abundance of the guild ground-nesting bird species is not related to predator control. This could indicate that game management is largely ineffective in reducing predator populations. For instance, there may have been movements of predators between managed and unmanaged areas (Towerton et al. 2011), and predator control may be compensated by the attraction of predators from neighbouring areas due to an increase in prey availability (DelibesMateos et al. 2007, Beja et al. 2009). Indeed, in our study, paired Game estates and Control areas (where predator control did not occur) were close (Figure 1 ), which may have resulted in a lack of marked differences in predator abundance paired managed and unmanaged areas.

As an alternative to the predation hypothesis, it is possible that positive effects on groundnesting species were due to factors such as habitat management. For instance, the cultivation of game crops to provide cover and food for game birds (Reino et al. 2000) may be beneficial for a range of farmland species (Martínez 1994, Stoate et al. 2003, Sage et al. 2005, Moreira et al. 2012), such as the steppe-birds included in our ground-nesting guild. Moreover, management of game crops may include delaying crop harvesting to protect nests from destruction of partridges (Casas and Vinũela 2010), which would also favour other ground-nesting species (Morgado and Moreira 200o). Additionally, provision of food and water for small game may have benefitted these species (Gaudioso Lacasa et al. 2010, Estrada et al. 2012). In any case, these trends were only apparent when taking into account habitat differences, and the overall magnitude of the effect was small (Table 4). In summary, although we provide evidences of some benefits of game management for some farmland birds (ground-nesting steppe-birds), suggesting a potential positive effect of food provision or cultivation of game crops, further studies are required to confirm this finding.

Raptor abundance was also higher in areas managed for Game estates than in Control areas. This may be related to the higher availability in managed areas of small game species such as partridges and rabbits (Beja et al. 2009, Table 2), which are potential prey for the species considered in our guild (Valkama et al. 2005). However, and contrary to our expectation, we did not find an important positive effect of partridge or rabbit abundance on both richness and abundance of raptors in the best $\mathrm{AIC}_{\mathrm{c}}$ models (Table 4). This suggests that other management tools, such as cultivation of game crops, could also favour higher abundance of raptors in Game estates, if there are better foraging grounds than other land uses, due to higher prey abundance or detectability (Janes 1985, Ferrer and Harte 1997, Ontiveros et al. 2005). 
Although the observed higher abundance of raptors in game estates suggests that hunting management may benefit this guild, it should also be noted that it would be necessary to evaluate whether source-sink dynamics are occurring, and whether higher observed richness and abundance are not also hiding a higher mortality. In this sense, Beja et al. (2009) found in the same study area that the abundance of certain raptor species was less than that expected from habitat or prey availability in areas with higher density of gamekeepers, suggesting potential persecution of raptors. Something similar has been also observed in other studies conducted in northern Europe (Anderson et al. 2009). Therefore, more studies should be carried out to completely understand the global effect of game management on raptor species.

Finally, our results showed that habitat was the most important variable for explaining variation in richness and abundance of guilds and species. Vegetation structural heterogeneity is quite often related to abundance or richness of songbirds (Mönkkönen 1994, Reino et al. 2009, Castro et al. 2010, Concepción and Díaz 2011, Pickett and Siriwardena 2011). In this sense, we found a positive relationship between habitat structural simplicity (large treeless areas, having only herbaceous or dwarf shrub cover) and farmland songbirds, but negative with scrubland songbirds. Also, abundance and richness of other guilds, and abundance of the three species of conservation concern, were explained by habitat, and were higher where habitat structural simplicity was more widespread. This is not surprising since many of the species observed during the surveys mainly occupy large areas of treeless and extensive cereal cultivation known as 'cereal pseudosteppes' (Suárez et al. 1997, Traba et al. 2007). In addition, these species generally avoid nesting in, or close to, tall or thick vegetation, which may favour higher abundances of generalist predators (Reino et al. 2009, 2010a,b, Červinka et al. 2011).

\section{Conclusions}

Broadly, our results suggest that low-intensity management actions directed at small game in the Iberian Peninsula do not seem to detrimentally affect any of the species or guilds studied, while it may have positive effects (albeit weak) on other species. Our findings are in agreement with those shown in earlier studies in Portugal (Borralho et al. 1998, Stoate et al. 2000) and elsewhere in Europe (Stoate and Szczur 2001, Mustin et al. 2011). This indicates that there is a potential for shared benefits and common objectives among hunters and those generally interested in wildlife conservation (Knezevic 2009), and that there are possibilities for developing management systems that specifically maximise both hunting sustainability and conservation value of managed areas.

With our data it was not possible to differentiate which management activities had higher (positive) impact on non-game species, and so there is a need to further investigate the consequences of specific game management on biodiversity, at both the local and landscape scales. However, the fact that our results showed that habitat variables were more important than game management for all guilds suggests that habitat improvement and maintenance of sustainable game populations is possibly the basis for the most long-term and large-scale benefits of hunting on bird conservation. Game management has resulted at times in improvements of habitat quality that have benefited directly (through increasing productivity or breeding success) and indirectly (improving or increasing their foraging and nesting habitats) other bird species (Chiverton and Sotherton 1991, Tharme et al. 2001, Sage et al. 2005). Additionally, the more common explanation for declines in many farmland bird populations, including game ones like the Red-legged Partridge, is habitat change, in the form of degradation, fragmentation or destruction (Donald et al. 2006, Reino et al. 2009). Therefore, management for game that leads to better habitat quality, associated with sustainable harvest strategies, could result in areas that have large conservation value (e.g. Robertson et al. 2001). In these cases, the maintenance of hunting would provide great opportunities to maintain the viability of these high-quality habitats, thus contributing to the conservation of farmland bird species. 


\section{Supplementary Material}

The supplementary materials referred to in this article can be found at journals.cambridge.org/bci

\section{Acknowledgements}

This study was funded by the Portuguese Foundation for Science and Technology (FCT) (PRAXIS/C/AGR/11062/1998) and by the European Commission under the 7 th Framework Programme for Research and Technological Development through the project HUNT (212160, FP7ENV-2007-1), and contributes to the project CGL2009-13029 from the Spanish Ministry of Science. J.C. had postdoctoral contract jointly financed by the ESF and by the Junta de Comunidades de Castilla-La Mancha (JCCM, Spain), in the framework of the Operational Programme FSE 20072013; AE has a postdoctoral contract funded by the project BIODIVERSA/0003/2011; LR and LG were funded by FCT through grants SFRH/BPD/62865/2009 and SFRH/BD/64645/2009, respectively; and MDM was supported by a JAE-doc contract (Programa Junta Para la Ampliación de Estudios), funded by CSIC and the European Social Fund. We thank the staff of ERENA, SA the Centre for Applied Ecology 'Baeta Neves' (Instituto Superior de Agronomia) and the Centre for Environmental Biology (Lisbon Faculty of Science) for collaboration in the development of the Project. We thank landowners and game managers who allowed access to their property and their willingness to provide information on their game management practices. Finally we thank Mario Díaz, José Tella, Phil Atkinson and an anonymous referee for constructive comments on the manuscript.

\section{References}

Anderson, B. J., Arroyo, B., Collingham, Y. C., Etheridge, B., Fernandez de Simon, J., Gillings, S., Gregory, R., Leckie, F., Thomas, C. D., Travis, J. and Redpath, S. (2009) Using distribution models to test alternative hypotheses about a species' environmental limits and recovery prospects. Biol. Conserv. 142: 488-499.

Atauri, J. A. and Lucio, J. V. (2001) The role of landscape structure in species richness distribution of birds, amphibians, reptiles and lepidopterans in Mediterranean landscapes. Landscape Ecol. 16: 147-159.

Bartoń, K. (2012) MuMIn: multi-model inference. R package version 1.7.I1. http://CRAN. R-project.org/package=MuMIn. Accessed 20 June 2012.

Beja, P., Gordinho, L., Reino, L., Loureiro, F., Santos-Reis, M. and Borralho, R. (2009) Predator abundance in relation to small game management in southern Portugal: conservation implications. Eur. J. Wildl. Res. 55: 227-238.

Beja, P., Schindler, S., Santana, J., Porto, M., Morgado, R., Moreira, F., Pita, R., Mira, A. and Reino, L. (2014) Predators and livestock reduce bird nest survival in intensive Mediterranean farmland. Eur. J. Wildl. Res. 6o: 249-258.
BirdLife International (2004) Birds in the European Union: a status assessment. Wageningen, The Netherlands: BirdLife International.

Blanco-Aguiar, J. A., González-Jara, P., Ferrero, M. E., Sánchez-Barbudo, I., Virgós, E., Villafuerte, R. and Dávila, J. A. (2008) Assessment of game restocking contributions to anthropogenic hybridization: the case of the Iberian red-legged partridge. Anim. Conserv. 11: 535-545.

Blanco-Aguiar, J. A., Virgós, E. and Villafuerte, R. (2004) Perdiz Roja (Alectoris rufa). Pp. 182-185 in A. Madroño, C. González and J. C. Atienza, eds. Libro Rojo de las aves de España. Madrid: Dirección General para la Biodiversidad-SEO/BirdLife.

Borralho, R., Stoate, C., Araújo, M., Rito, A. and Carvalho, S. (1998) Factores ambientais que afectaram a ocorrência primaveril de Codorniz Coturnix coturnix no Baixo Alentejo. Pp 68-72 in L. T. Costa, H. Costa, M. Araújo and M. A. Silva, eds. Actas do simpósio sobre aves migradoras na Península Ibérica, Évora, Portugal.

Burnham, K. P. and Anderson, D. R. (2002) Model selection and multimodel inference: 
a practical information-theoretic approach, 2nd edn. New York: Springer-Verlag.

Cabral, M. J., Almeida, J., Almeida, P. R., Dellinger, T., Ferrand de Almeida, N., Oliveira, M. E., Palmeirim, J. M., Queiroz, A. I., Rogado, L. and Santos-Reis, M. (2008) Livro Vermelho dos vertebrados de Portugal. 3 rd edition. Lisboa: Instituto de Conservação da Natureza/Zahirió and Alvim.

Calvete, C., Pelayo, E. and Sampietro, J. (2006) Habitat factors related to wild rabbit population trends after the initial impact of rabbit haemorrhagic disease. Wildl. Res. 33: 467-474.

Casas, F., Mougeot, F., Viñuela, J. and Bretagnolle, V. (2009) Effects of hunting on the behaviour and spatial distribution of farmland birds: importance of hunting-free refuges in agricultural areas. Anim. Conserv. 12: 346-354.

Casas, F. and Viñuela, J. (2010) Agricultural practices or game management: which is the key to improve red-legged partridge nesting success in agricultural landscapes? Environ. Conserv. 37: 177-186.

Castro, J., Moreno-Rueda, G. and Hódar, J. A. (2010) Experimental test of postfire management in pine forests: impact of salvage logging versus partial cutting and nonintervention on bird-species assemblages. Conserv. Biol. 24: 810-819.

Červinka, J., Šálek, M., Pavluvčík, P. and Kreisinger, J. (2011) The fine-scale utilization of forest edges by mammalian mesopredators related to patch size and conservation issues in Central European farmland. Biodivers. Conserv. 20: 3459-3475.

Chazara, O., Minvielle, F., Roux, D., Bed'hom, B., Feve, K., Coville, J-L., Kayang, B. B., Lumineau, S., Vignal, A., Boutin, J-M. and Rognon, X. (2010) Evidence for introgressive hybridization of wild common quail (Coturnix coturnix) by domesticated Japanese quail (Coturnix japonica) in France. Conserv. Genet. 11: 1051-1062.

Chiverton, P. A. and Sotherton, N. W. (1991) The effects on beneficial arthropods of the exclusion of herbicides from cereal crop edges. J. Appl. Ecol. 28: 1027-1039.

Coelho, M. P. (2011). Hunting rights and conservation: The Portuguese case. Int. J. Latest Trends Fin. Eco. Sc. 1: 164-170.
Concepción, E. D. and Díaz, M. (2011) Field, landscape and regional effects of farmland management on specialist open-land birds: Does body size matter? Agr. Ecosyst. Environ. 142: 303-310.

Delibes-Mateos, M., Redpath, S. M., Angulo, E., Ferreras, P. and Villafuerte, R. (2007) Rabbits as a keystone species in southern Europe. Biol. Conserv. 137: 149-156.

Díaz, M., Campos, P. and Pulido, F. J. (2009) Importancia de la caza en el desarrollo sustentable y en la conservación de la biodiversidad. Pp 21-33 in M. Sáez de Buruaga and J. Carranza, eds. Gestión cinegética en ecosistemas Mediterráneos. Sevilla, Spain: Consejería de Medio Ambiente de la Junta de Andalucía.

Donald, P. F., Green, R. E. and Heath, M. F. (2001) Agricultural intensification and the collapse of Europe's farmland bird populations. Proc. Roy. Soc. Lond. 268: 25-29.

Donald, P. F., Sanderson, F. J., Burfield, I. J. and van Bommel, F. P. J. (2006) Further evidence of continent-wide impacts of agricultural intensification on European farmland birds, 1990-2000. Agr. Ecosyst. Environ. 116: 189-196.

Estrada, A., Caro, J., Beja, P., Borralho, L., Casas, F., Delibes-Mateos, M. DíazFernández, S., Gordinho, L., Reino, L., Viñuela, J., and Arroyo, B. (2012) Does hunting management affect non-game bird species? Pp 97 in Proceedings of the International Conference on Hunting for Sustainability: ecology, economics and society. IREC, Ciudad Real, Spain.

Evans, D. M. and Day, K. R. (2002) Hunting disturbance on a large shallow lake: the effectiveness of waterfowl refuges. Ibis 144: 2-8.

Ferrer, M. and Harte, M. (1997) Habitat selection by immature Spanish imperial eagles during the dispersal period. J. Appl. Ecol. 34: 1359-1364.

Fletcher, K., Aebischer, N. J., Baines, D., Foster, R. and Hoodless, A. N. (2010) Changes in breeding success and abundance of groundnesting moorland birds in relation to the experimental deployment of legal predator control. J. Appl. Ecol. 47: 263-272.

Fournier, D. A., Skaug, H. J., Ancheta, J., Ianelli, J., Magnusson, A., Maunder, M., Nielsen, A. and Sibert, J. (2012) AD Model Builder: 
using automatic differentiation for statistical inference of highly parameterized complex nonlinear models. Optim. Method. Softw. 27: 233-249.

Gaudioso Lacasa, V. R., Sánchez García-Abad, C., Prieto Martín, R., Bartolomé Rodríguez, D. J., Pérez Garrido, J. A. and Alonso de La Varga, M. E. (2010) Small game water troughs in a Spanish agrarian pseudo steppe: visits and water site choice by wild fauna. Eur. J. Wildl. Res. 56: 591-599.

Halliday, T. R. (1980) The extinction of the passenger pigeon Ectopistes migratorius and its relevance to contemporary conservation. Biol. Conserv. 17: 157-162.

Hartway, C. and Mills, L. S. (2012) A metaanalysis of the effects of common management actions on the nest success of North American birds. Conserv. Biol. 26: 657-666.

Janes, S. W. (1985) Habitat selection in raptorial birds. Pp 159-184 in M. L. Cody, ed. Habitat selection in birds. San Diego, USA: Academic Press.

Keane, A., Brooke, M. de L. and McGowan, P. J. K. (2005) Correlates of extinction risk and hunting pressure in gamebirds (Galliformes). Biol. Conserv. 126: 216-233.

Knezevic, I. (2009) Hunting and environmentalism: Conflict or misperceptions. Human Dimensions of Wildlife 14: 12-20.

Leopold, A. (1986) Game management. Wisconsin, USA: The University of Wisconsin Press.

Litteral, J. and Wu, J. (2012) Urban landscape matrix affects avian diversity in remnant vegetation fragments: Evidence from the Phoenix metropolitan region, USA. Urban Ecosyst. 15: 939-959.

Macaulay, L. T., Starrs, P. F. and Carranza, J. (2013) Hunting in managed oak woodlands: contrasts among similarities. Pp. 311-350 in P. Campos, L. Huntsinger, J. L. Oviedo, M. Díaz M, P. Starrs, R. B. Standiford and G. Montero, eds. Mediterranean oak woodland working landscapes: Dehesas of Spain and Ranchlands of California. New York, USA: Springer.

Mace, G., Masundire, H. and Baille, J. (2005) Biodiversity. Pp. 77-122 in Assessment's Condition and Trends Working Group, ed. Millennium Ecosystems and human wellbeing:current state and trends. Washington, USA: Island Press.
Magaña, M., Alonso, J. C., Martín, C. A., Bautista, L. M. and Martín, B. (2010) Nest-site selection by Great Bustards Otis tarda suggests a trade-off between concealment and visibility. Ibis 152: 77-89.

Martínez, J., Viñuela, J. and Villafuerte, R. (2002) Socio-economic aspects of gamebird hunting, hunting bags and assessment of the status of gamebird populations. In REGHAB countries. Part 1: Socioeconomic and cultural aspects of gamebird hunting. Report on Workpackage $I$ of the European Project REGHAB N ${ }^{\circ}$ EKV- 2000-00637.

Martínez, C. (1994) Habitat selection by the little bustard Tetrax tetrax in cultivated areas of Central Spain. Biol. Conserv. 67: 125-128.

Mateo-Moriones, A., Villafuerte, R. and Ferreras, P. (2012) Does fox control improve red-legged partridge (Alectoris rufa) survival? An experimental study in Northern Spain. Anim. Biodivers. Conserv. 35: 395-404.

Mazerolle, M. J. (2012) AICcmodavg: Model selection and multimodel inference based on (Q)AIC(c). R package version 1.26. http:// CRAN.Rproject.org/package=AICcmodavg.

Morales, M. B., Guerrero, I., Oñate, J. J. and Meléndez, L. (2012) Inter-specific association and habitat use in a farmland passerine assemblage. Ecol. Res. 27: 691-700.

Moreira, F., Silva, J. P., Estanque, B., Palmeirim, J. M., Lecoq, M., et al. (2012) Mosaic-level inference of the impact of land cover changes in agricultural landscapes on biodiversity: A case-study with a threatened grassland bird. PLoS ONE 7(6): e38876. doi:10.1371/ journal.pone.0038876.

Mönkkönen, M. (1994) Diversity patterns in Palearctic and Nearctic forest bird assemblages. J. Biogeogr. 21: 183-195.

Morgado, R. and Moreira, F. (2000) Seasonal population dynamics, nest site selection, sexratio and clutch size of the great bustard Otis tarda in two adjacent lekking areas. Ardeola 47: $237-246$.

Mustin, K., Newey, S., Irvine, J., Arroyo, B. and Redpath, S. (2011) Biodiversity impacts of game bird hunting and associated management practices in Europe and North America. Report to RSPB.

Myers, N., Mittermeier, R. A., Mittermeier, C. G., da Fonseca, G. A. B. and Kent, J. (2000) 
Biodiversity hotspots for conservation priorities. Nature 403: 853-858.

Naidoo, R., Weaver, L. C., Stuart-Hill, G. and Tagg, J. (201I) Effect of biodiversity on economic benefits from communal lands in Namibia. J. Appl. Ecol. 48: 310-316.

Oldfield, T. E. E., Smith, R. J., Harrop, S. and Leader-Williams, N. (2003) Field sports and conservation in the United Kingdom. Nature 423: 531-533.

Ontiveros, D., Pleguezuelos, J. M. and Caro, J. (2005) Prey density, prey detectability and food habits: the case of Bonelli's eagle and the conservation measures. Biol. Conserv. 123: 19-25.

Pain, D. J. and Pienkowski, M. W. (1997) Farming and birds in Europe. The common agricultural policy and its implications for bird conservation. London, UK: Academic Press.

Paulson, N. (2012) The place of hunters in global conservation advocacy. Conserv. Soc. 10: 53-62.

Pickett, S. R. A. and Siriwardena, G. M. (2011) The relationship between multi-scale habitat heterogeneity and farmland bird abundance. Ecography 34: 955-969.

Pinto-Correia, T. and Mascarenhas, J. (1999) Contribution to the extensification/ intensification debate: new trends in the Portuguese montado. Landscape Urban Plan. 46: 125-131.

R Development Core Team (2011) R: A language and environment for statistical computing. R Foundation for Statistical Computing, Vienna. Accessed 20 June 2012.

Reino, L., Beja, P., Osborne, P. E., Morgado, R., Fabião, A. and Rotenberry, J. T. (2009) Distance to edges, edge contrast and landscape fragmentation: interactions affecting farmland birds around forest plantations. Biol. Conserv. 142: 824-838.

Reino, L. M., Borralho, R. and Bugalho, J. F. F. (2000) Revisão da utilização de culturas para a fauna na gestão de aves cinegéticas. Revista de Ciências Agrárias 23: 48-71.

Reino, L., Porto, M., Morgado, R., Carvalho, F., Mira, A. and Beja, P. (2010a) Does afforestation increase bird nest predation risk in surrounding farmland? Forest. Ecol. Manage. 260: 1359-1366.

Reino, L., Porto, M., Morgado, R., Moreira, F., Fabião, A., Santana, J., Delgado, A., Gordinho,
L., Cal, J. and Beja, P. (201ob) Effects of changed grazing regimes and habitat fragmentation on Mediterranean grassland birds. Agricult. Ecosys. Environ. 138: 27-34.

Robertson, P. A., Park, K. J. and Barton, A. F. (2001) Loss of heather Calluna vulgaris moorland in the Scottish uplands: the role of red grouse Lagopus lagopus scoticus management. Wildl. Biol. 7: 11-16.

Sage, R. B., Parish, D. M. B., Woodburn, M. I. A., Thompson, P. G. L. (2005) Songbirds using crops planted on farmland as cover for game birds. Eur. J. Wildl. Res. 51: 248-253.

Sokos, C. K., Mamolos, A. P., Kalburtji, K. L. and Birtsas, P. K. (2013) Farming and wildlife in Mediterranean agroecosystems. J. Nat. Conserv. 21: 81-92.

Stoate, C. and Szczur, J. (2001) Could game management have a role in the conservation of farmland passerines? A case study from a Leicestershire farm. Bird Study 48: 279-292.

Stoate, C., Borralho, R. and Araújo, M. (200o) Factors affecting corn bunting Miliaria calan$\mathrm{dra}$ abundance in a Portuguese agricultural landscape. Agr. Ecosyst. Environ. 77: 219-226.

Stoate, C., Szczur, J. and Aebischer, N. J. (2003) Winter use of wild bird cover crops by passerines on farmland in northeast England. Bird Study 50: 15-21.

Suárez, F., Naveso, M. A. and De Juana, E. (1997) Farming in the drylands of Spain: birds of pseudosteppes. Pp. 79-116 in D. J. Pain and N. W. Pienkowski, eds. Farming and birds in Europe. The common agricultural policy and its implications for bird conservation. San Diego, UK: Academic Press.

Suárez, F., Yanes, M., Herranz, J. and Manrique, J. (1993) Nature reserves and the conservation of Iberian shrubsteppe passerines: The paradox of nest predation. Biol. Conserv. 64: 77-81.

Tellería, J. L., Asensio, B. and Díaz, M. (1999) Aves Ibéricas II. Paseriformes. Madrid, Spain: J. M. Reyero.

Tharme, A. P., Green, R. E., Baines, D., Bainbridge, I. P. and O'Brien, M. (2001) The effect of management for red grouse shooting on the population density of breeding birds on heather-dominated moorland. J. Appl. Ecol. 38: 439-457.

Thiollay, J. M. (2005) Effects of hunting on guianan forest game birds. Biodivers. Conserv. 14: I121-1135. 
Towerton, A. L., Penman, T. D., Kavanagh, R. P. and Dickman, C. R. (2011) Detecting pest and prey responses to fox control across the landscape using remote cameras. Wildlife. Res. 38: 208-220.

Traba, J., García de la Morena, E. L., Morales, M. B. and Suárez, F. (2007) Determining high value areas for steppe birds in Spain: hot spots, complementarity and the efficiency of protected areas. Biodivers. Conserv. 16: 3255-3275.

Van Doorn, A. M. and Bakker, M. M. (2007) The destination of arable land in a marginal agricultural landscape in South Portugal: an exploration of land use change determinants. Landscape Ecol. 22: 1073-1087.

Valkama, J., Korpimäki, E., Arroyo, B., Beja, P., Bretagnolle, V., Bro, E., Kenward, R., Mañosa, S., Redpath, S., Thirgood, S. and Viñuela, J. (2005) Birds of prey as limiting factors of gamebird populations in Europe: a review. Biol. Rev. 80: 171-203.

Verner, J. (1984) The guild concept applied to management of bird populations. Env. Manage. 8: 1-13.

Villafuerte, R., Calvete, C., Blanco, J. C. and Lucientes, J. (1995) Incidence of viral hemorrhagic disease in wild rabbit populations in Spain. Mammalia 59: 651-659.
Villafuerte, R., Viñuela, J. and Blanco, J. C. (1998) Extensive predator persecution caused by population crash in a game species: The case of red kites and rabbits in Spain. Biol. Conserv. 84: 181-188.

Villanúa, D., Pérez-Rodríguez, L., Casas, F., Alzaga, V., Acevedo, P., Viñuela, J. and Gortázar, C. (2008) Sanitary risks of redlegged partridge releases: introduction of parasites. Eur. J. Wildl. Res. 54: 199-204.

Virgós, E. and Travaini, A. (2005) Relationship between small-game hunting and carnivore diversity in central Spain. Biodivers. Conserv. 14: 3475-3486.

Whitfield, D. P., McLeod, D. R. A., Watson, J., Fielding, A. H. and Haworth, P. F. (2003) The association of grouse moor in Scotland with the illegal use of poisons to control predators. Biol. Conserv. 114: 157-163.

Woodroffe, R., Thirgood, S. J. and Rabinowitz, A. (2005) People and wildlife: conflict or coexistence? Cambridge, UK: Cambridge University Press.

Yanes, M. and Suárez, F. (1996) Incidental nest predation and lark conservation in an Iberian semiarid shrubsteppe. Conserv. Biol. 10: $881-887$.

Zar, J. H. (1999) Biostatistical analysis, $4^{\text {th }}$ edn. London, UK: Prentice-Hall.

\section{JESÚS CARO*, MIGUEL DELIBES-MATEOS, ALBA ESTRADA, BEATRIZ ARROYO}

Instituto de Investigación en Recursos Cinegéticos - IREC (CSIC-UCLM-JCCM),

Ronda de Toledo s/n. 13071. Ciudad Real, Spain.

ALBA ESTRADA

CIBIO/InBio, Universidade de Évora, Casa Cordovil $2^{\circ}$ andar, Rua Dr. Joaquim Henrique da Fonseca, 70oo-89o, Évora, Portugal.

RUI BORRALHO, LUÍS GORDINHO

ERENA, SA, Rua Robalo Gouveia, SA, 1-1A, 1900-392 Lisboa, Portugal.

LUÍS GORDINHO, LUÍS REINO, PEDRO BEJA

EDP Biodiversity Chair, CIBIO/InBio, Centro de Investigação em Biodiversidade e

Recursos Genéticos, Universidade do Porto, Campus Agrário de Vairão, Rua Padre

Armando Quintas, 4485-661 Vairão, Portugal.

*Author for correspondence; e-mail: jcaro@ugr.es

Received 28 May 2013; revision accepted 15 January 2014; Published online 8 October 2014 